\title{
UJI EFEK ANALGESIK EKSTRAK ETANOL DAUN KUCAI (Allium tuberosum) PADA TIKUS PUTIH JANTAN (Rattus norvegicus)
}

\section{ANALGETIC EFFECT TEST FROM ETHANOL EXTRACT OF KUCAI LEAVES (Allium tuberosum) ON MALE WHITE RATS (Rattus norvegicus)}

\author{
Dwilanda E. Turama ${ }^{1)}$, Widdhi Bodhi ${ }^{1)}$, Imam Jayanto ${ }^{1)}$ \\ ${ }^{1)}$ Program Studi Farmasi FMIPA UNSRAT Manado, 95115 \\ *Dwilandat@gmail.com
}

\begin{abstract}
Kucai (Allium tuberosum) leaves contain metabolite compounds such as alkaloids, saponins, tannis which are potential sources to be developed as medical plants. Flavonoid is a derivative pf a phenol that has an analgesic properties. This study aims to determine whether there is an analgesic effect on the ethanol extract of kucai leaves. This study uses a laboratory experimental research design using wistar strain male white rats as an experiment animal. The ethanol extract of kucai leaves are given with different doses, group 1 doses 3,6 mg, group 2 doses 7,2 $\mathrm{mg}$ and group 3 doses $14,4 \mathrm{mg}$. Stimulation method in rats was carried out by using a $55^{\circ} \mathrm{C}$ hot plate. Rats was observed before and after giving test material at 30, 60, 90 and 120 minutes respectively and observed their responses by the form of licking legs and jumping. From the result of data in the form of tables and charts show that the ethanol extract of kucai leaves with doses 3,6 mg, 7,2 $\mathrm{mg}$, and 14,4 $\mathrm{mg}$ has analgesic effect. It can be concluded that the best analgesic effect of doses is doses 14,4 $\mathrm{mg}$.
\end{abstract}

Keyword : Analgesic, kucai, male white rats

\begin{abstract}
ABSTRAK
Daun Kucai (Allium tuberosum) memiliki kandungan senyawa metabolit seperti alkaloid, saponin, tanin, dan flavonoid yang merupakan sumber potensial untuk dikembangkan sebagai tanaman obat. Flavonoid merupakan turunan senyawa fenol yang memiliki sifat analgetik. Penelitian ini bertujuan untuk mengetahui adanya efek analgesik dari ekstrak etanol daun kucai. Penelitian ini menggunakan Rancangan Penelitian eksperimental laboratorium menggunakan tikus putih jantan galur wistar sebagai hewan percobaan. Ekstrak etanol daun kucai diberikan dengan dosis yang berbeda-beda yaitu kelompok perlakuan 1 dengan dosis 3,6 mg, perlakuan 2 dengan dosis 7,2 mg, perlakuan 3 dengan dosis 14,4 mg. Metode rangsangan pada tikus dilakukan dengan menggunakan hot plate dengan suhu $55^{\circ} \mathrm{C}$. Tikus di amati sebelum dan setelah pemberian bahan uji, menit ke 30, 60, 90, dan 120. Respon tikus yang diamati berupa menjilat kaki dan melompat. Dari hasil analisis data dalam bentuk tabel, grafik dan diagram menunjukkan bahwa ekstrak etanol daun kucai dengan dosis 3,6 mg, 7,2 mg, dan 14,4 mg memiliki efek analgesik. Dapat disimpulkan bahwa dosis yang memiliki efek analgesik terbaik ialah dosis 14,4 mg.
\end{abstract}

Kata kunci: Analgesik, kucai, tikus putih jantan 


\section{PENDAHULUAN}

Rasa nyeri merupakan mekanisme perlindungan terhadap kerusakan jaringan yang menyebabkan individu bereaksi dengan cara memindahkan posisi tubuhnya. Rasa nyeri dapat ditimbulkan dengan rangsangan suhu (Guyton et al., 2007). Rasa nyeri yang disebabkan rangsangan mekanisme atau kimiawi, kalor, atau listrik, yang dapat menimbulkan kerusakan jaringan dan melepaskan zat yang disebut mediator nyeri (Anief, 2000).

Analgesik adalah obat yang digunakan untuk mengurangi rasa nyeri tanpa menghilangkan kesadaran. Obat analgesik memperngaruhi ambang kesadaran akan perasaaan sakit. Obat penghalang nyeri (analgesik) mempengaruhi proses pertama dengan mempertinggi ambang kesadaran akan perasaan sakit, sedangkan narkotik menekan reaksireaksi psikis yang diakibatkan oleh rangsangan sakit (Anief, 2000).

Salah satu jenis tanaman dapat dimanfaatkan sebagai obat adalah kucai (Allium tuberosum). Daun kucai mengandung zat gizi seperti kalori, protein, lemak, karbohidrat, kalsium, fosfor, besi dan vitamin (Andarwulan et al., 2012). Daun kucai juga mengandung berbagai senyawa fitokimia antara lain alkaloid, flavonid, glikosida, steroid dan tanin (Al-Snafi, 2013).

Flavonoid merupakan turunan senyawa fenol yang umumnya memiliki sifat analgetik, antiinflamasi, meningkatkan mortilitas usus, antimikroba, dan lainnya (Andawulan et al., 2012). Flavonoid menunjukkan lebih dari seratus macam bioaktivitas. Bioaktivitas yang ditunjukkan antara lain efek antipiretik, analgesik, dan antiinflamasi (Wijayakusuma, 2001).

\section{METODOLOGI PENELITIAN Waktu dan Tempat Penelitian}

Penelitian ini berlangsung mulai dari bulan November 2019 - Juni 2020. Penelitian dilakukan di Laboratorium Penelitian dan Laboratorium Farmakologi Program Studi Farmasi Fakultas Matematika dan Ilmu Pengetahuan Alam, Universitas Sam Ratulagi Manado.

\section{Rancangan Penelitian}

Penelitian ini menggunakan rancangan eksperimental dengan menggunakan tikus putih jantan sebagai hewan percobaan. Ada 5 macam perlakuan terhadap hewan uji. Kelompok 1 sebagai kontrol negatif diberi $\mathrm{CMC} 1 \%$. Kelompok 2 sebagai kontrol positif diberi parasetamol. Kelompok 3-5 diberi perlakuan ekstrak etanol daun kucai dengan dosis yaitu 3,6 mg, 7,2 mg, 14,4 mg.

\section{Alat dan Bahan}

Alat

Alat yang akan digunakan dalam penelitian ini, yaitu kandang pemeliharaan hewan, sarung tangan, tempat air minum dan makanan hewan, alat gelas, timbangan analitik, timbangan tepung, blender, ayakan, oven, sarung tangan, masker, sudip, kertas saring, pot salep, pipet ukur, lumpang, alu, hot plate, stopwatch, disposable syringe $1 \mathrm{ml}$, dan sonde oral.

\section{Bahan}

Bahan yang digunakan yaitu tikus putih jantan sejumlah 15 ekor, ekstrak daun kucai, aquades, etanol $96 \%$, pakan tikus putih, parasetamol, CMC $1 \%$.

\section{Prosedur Penelitian}

\section{Penyiapan dan Pengambilan Sampel}

Daun kucai (Allium tuberosum) diperoleh dari desa Kakaskasen Tiga, kecamatan Tomohon Utara, kota Tomohon, provinsi Sulawesi Utara. Daun kucai dicuci bersih dengan air mengalir, ditiriskandan di timbang berat basahnya kemudian dikeringkan dengan menggunakan oven pada suhu $40^{\circ} \mathrm{C}$. Setelah kering kemudian dihaluskan dengan menggunakan blender dan diayak hingga diperoleh simplisia.

\section{Ekstraksi}

Simplisia yang telah ditimbang sebanyak 200 gram dimasukkan kedalam wadah, kemudian ditambahkan pelarut etanol $96 \%$ sebanyak $1000 \mathrm{ml}$ dengan perbandingan 1:5 sampai sampel terendam secara keseluruhan kemudian sampel ditutup, perendaman dilakukan selama 5 hari dan terlindung dari cahaya. Selama perendaman dilakukan pengadukan setiap hari. Setelah 5 hari, dilakukan penyaringan menggunakan kertas saring menghasilkan filtrat dan debris. Selanjutnya dilakukan proses remaserasi dengan ekstrak etanol 96\% sebanyak $600 \mathrm{ml}$ dengan perbandingan 1:3 selama 3 hari. Filtrat yang peroleh digabungkan dan dipekatkan menggunakan oven pada suhu $40^{\circ} \mathrm{C}$ sampai diperoleh ekstrak kental. 


\section{Pembuatan Larutan CMC 1\%}

CMC 1\% sebanyak 1 gram ditaburkan dalam beaker glass yang sudah berisi $10 \mathrm{ml}$ aquades yang dipanaskan, aduk sampai megembang hingga homogen. Selanjutnya dimasukkan kedalam labu ukur dan ditambahkan aquades sampai $100 \mathrm{ml}$.

\section{Penyiapan Suspensi Paracetamol}

Dosis parasetamol untuk manusia adalah 500 $\mathrm{mg}$, maka dosis parasetamol untuk tikus putih adalah $500 \mathrm{mg} \times 0,018=9 \mathrm{mg}(0,018$ merupakan faktor konversi dosis manusia ke tikus putih). Kemudian dilakukan uji keseragaman bobot. Tablet parasetamol $500 \mathrm{mg}$ ditimbang sebanyak 20 tablet untuk uji keseragaman bobot, kemudian digerus dan ditimbang berat serbuk. Serbuk parasetamol diambil sebanyak $108 \mathrm{mg}$ setelah dilakukan perhitungan uji keseragaman bobot kemudian dimasukkan dalam mortar dan ditambahkan dengan suspensi CMC 1\% sedikit demi sedikit sambil digerus hingga homogen, lalu dimasukkan ke dalam labu ukur 10 $\mathrm{ml}$. Kemudian volumenya dicukupkan hingga $10 \mathrm{ml}$ dengan suspensi CMC $1 \%$.

\section{Penyiapan Hewan Uji}

Penelitian ini menggunakan tikus jantan sebagai hewan uji yang terbagi atas 5 kelompok. Setiap kelompok terdiri atas 3 ekor tikus jantan galur wistar yang dipelihara dalam kandang. Hewan uji diadaptasi selama kurang lebih 2 minggu sebelum perlakuan. Semua tikus mulai diadaptasikan dengan tempat tinggal yang baru serta pemberian makanan dan minuman yang teratur.

\section{Metode Nyeri Panas}

Metode ini dilakukan dengan melihat respon tikus berupa melompat dan atau menjilat saat diberi rangsangan panas. Respon tikus berupa lompatan dan atau jilatan merupakan reaksi nyeri yang ditimbulkan oleh rangsangan panas (Mantiri et al, 2013).

\section{Pengujian}

Langkah-langkah pengujian efek analgetik pada hewan uji ialah sebagai berikut :

1. Beaker glass diletakkan di atas hot plate, kemudian hot plate dipanaskan hingga suhu $55^{\circ} \mathrm{C}$. Setelah suhu mencapai $55^{\circ} \mathrm{C}$ tikus dimasukkan kedalam beaker glass tersebut.

2. Setelah tikus ada didalam beaker glass maka responnya diamati, yaitu berupa gerakan menjilat kaki atau melompat. Pengamatan dilakukan selamat 1 menit.

3. Pengujian pada tikus jantan putih kelompok 1 diberi CMC $1 \%$ sebagai kontrol negatif . Kelompok 2 sebagai kontrol positif diberi parasetamol. Kelompok 3-5 diberi perlakuan ekstrak daun kucai dengan dosis yaitu 3,6 mg; $7,2 \mathrm{mg} ; 14,4 \mathrm{mg}$. Pengamatan dilakukan saat sebelum pemberian bahan uji, setelah pemberian bahan uji, pada menit ke 30,60, 90, dan menit ke 120.

\section{Analisis Data}

Data hasil pengamatan dikumpulkan dan disajikan dalam bentuk tabel, grafik, dan diagram untuk mengetahui pengaruh efek analgesik ekstrak etanol daun kucai (Allium tuberosum) terhadap tikus putih jantan (Rattus norvegicus).

\section{HASIL DAN PEMBAHASAN}

Data hasil penelitian berikut ialah data yang diperoleh dari ke 5 kelompok perlakuan hewan uji yang masing-masing kelompok terdiri dari 3 ekor hewan uji tikus. Hasil rata-rata penurunan respon tikus (geliat) terhadap kontrol negatif, kontrol positif dan ekstrak etanol daun kucai dapat dilihat sebagai berikut 
Tabel 1. Hasil rata-rata penurunan respon tikus sebelum dan sesudah pemberian bahan uji

\begin{tabular}{|c|c|c|c|c|c|}
\hline \multirow{2}{*}{$\begin{array}{l}\text { Kelompok } \\
\text { Perlakuan }\end{array}$} & \multirow{2}{*}{$\begin{array}{c}\text { Sebelum } \\
\text { Pemberian } \\
\text { Bahan Uji }\end{array}$} & \multicolumn{4}{|c|}{ Setelah Pemberian Bahan Uji } \\
\hline & & Menit Ke-30 & Menit Ke-60 & Menit Ke-90 & $\begin{array}{c}\text { Menit } \\
\text { Ke-120 }\end{array}$ \\
\hline $\mathbf{K}(-)$ & 14,3 & 12,3 & 11,6 & 12,3 & 13,6 \\
\hline $\mathbf{K}(+)$ & 11,6 & 4,6 & 2,6 & 0,6 & 0 \\
\hline KP1 & 12 & 12,3 & 9,6 & 4,6 & 1.6 \\
\hline KP2 & 13,3 & 8,3 & 6 & 3 & 1 \\
\hline KP3 & 11 & 6,3 & 3,6 & 1 & 0 \\
\hline
\end{tabular}

\section{Keterangan :}

$\mathrm{K}(-)$ : Kelompok kontrol negatif

$\mathrm{K}(+)$ : Kelompok kontrol positif

KP1 : Kelompok perlakuan ekstrak daun kucai dosis 3,6 mg

KP2 : Kelompok perlakuan ekstrak daun kucai dosis 7,2 mg

KP3 : Kelompok perlakuan ekstrak daun kucai dosis 14,4 mg

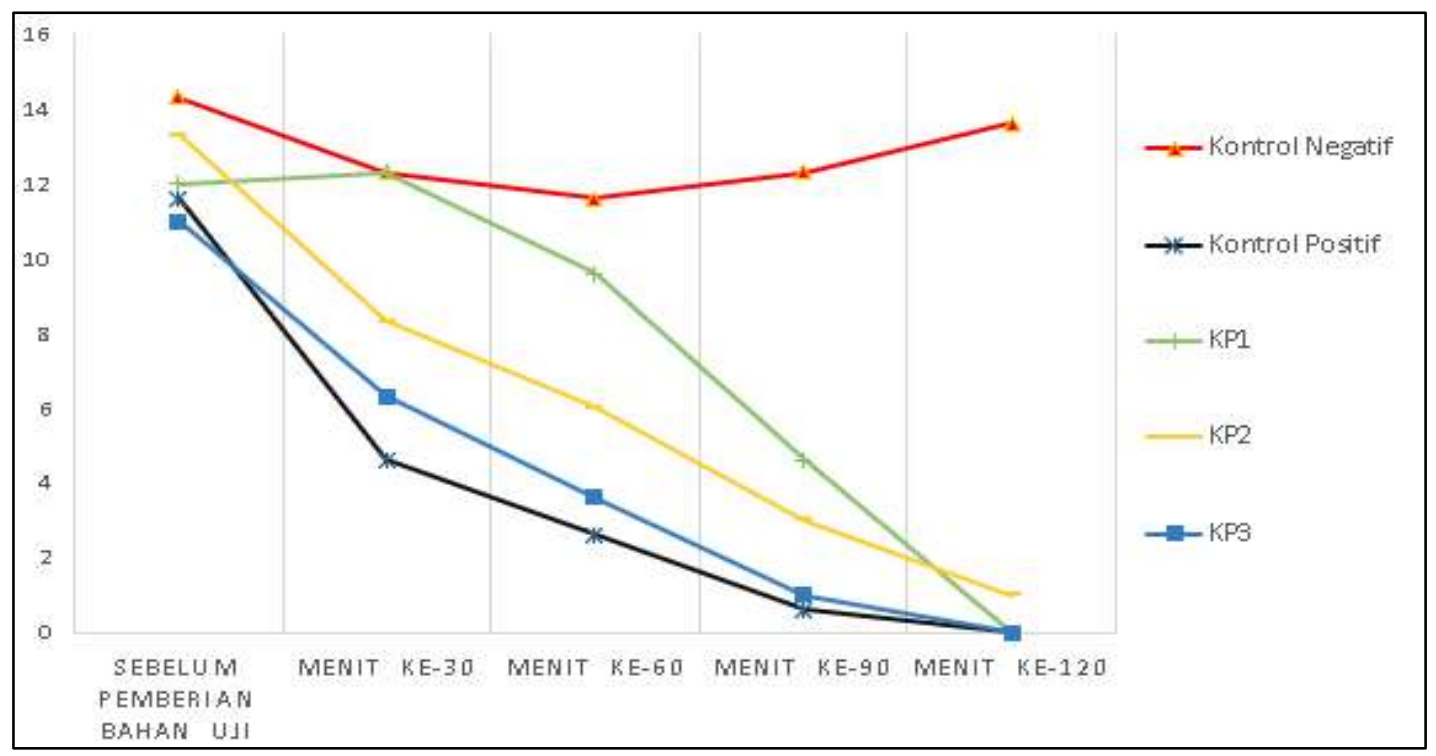

Gambar 1. Grafik rata-rata penurunan respon tikus

\section{Keterangan :}

Sumbu x : waktu pengujian

Sumbu y : rangka rata-rata

Penelitian ini menggunakan 15 ekor tikus yang dibagi dalam 5 kelompok perlakuan yang terdiri dari kontrol negatif, kontrol positif dan ekstrak etanol daun kucai dengan dosis 3,6 mg, 7,2 mg dan
14,4 mg yang bertujuan untuk mengetahui ada tidaknya efek analgetik dari ekstrak etanol daun kucai terhadap hewan uji yang menggunakan metode rangsangan panas. Rangsangan panas yang 
dilakukan terhadap hewan uji untuk memberi rangsangan nyeri, dengan cara tikus dimasukkan kedalam gelas beaker yang berada di atas hot plate pada suhu $55^{\circ} \mathrm{C}$. Pada penelitian ini respon hewan uji yang dinilai berupa gerakan menjilat kaki belakang atau melompat sebagai ketentuan hewan uji mulai merasakan nyeri. Penelitian ini menggunakan suhu $55^{\circ} \mathrm{C}$ karena suhu diatas $45^{\circ} \mathrm{C}$ mulai terjadi kerusakan jaringan akibat panas dan sensasinya berubah menjadi nyeri (Guyton, 2011). Penelitian ini menggunakan tikus sebagai hewan uji.

Kelompok kontrol negatif yang diberikan CMC $1 \%$ sebelum dan setelah pemberian bahan uji hingga menit ke 120 menunjukkan rata-rata jumlah respon tidak mengalami penurunan yang signifikan dari menit ke 30 hingga menit ke 120 respon tikus semakin tinggi. Penurunan rata-rata jumlah respon tikus pada kontrol negatif menunjukkan penurunan rata-rata jumlah respon tikus yang paling kecil diantara kelompok kontrol lainnya. Hal ini disebabkan karena pada kontrol negatif CMC $1 \%$ tidak terkandung zat aktif yang dapat mengurangi rasa nyeri.

Pada kelompok perlakuan kontrol positif yang diberi parasetamol menunjukkan penurunan jumlah rata-rata respon tikus terhadap rangsangan nyeri. Efek analgesik dari kelompok kontrol positif mulai terlihat setelah pemberian bahan uji pada menit ke 30 hingga menit ke 120. Paracetamol diketahui mencapai kadar puncak dalam plasma dalam waktu 30-60 menit dan memiliki waktu paruh 1-3 jam (Tjay et al., 2002).

Hasil pengujian pada kelompok perlakuan ekstrak daun kucai yang diberi dosis yang berbeda menunjukkan adanya efek analgetik. Dapat dilihat pada penurunan rata-rata jumlah respon nyeri pada tikus dari sebelum pemberian bahan uji dan setelah pemberian hingga menit ke 120. Pengujian kelompok perlakuan satu ekstrak daun kucai dengan dosis 3,6 mg, hasil menunjukkan respon tikus terhadap nyeri pada menit ke 30 terus terjadi penurunan hingga menit ke 120. Hal ini menunjukkan bahwa ekstrak daun kucai dosis 3,6 mg memiliki efek analgesik.

Pengujian kelompok perlakuan dua ekstrak daun kucai dosis 7,2 mg, hasil menunjukkan adanya respon tikus terhadap nyeri dilihat dari setelah pemberian bahan uji pada menit ke 30 terjadi penurunan hingga menit ke 120. Hal ini menunjukkan bahwa ekstrak daun kucai dosis 7,2 mg memiliki efek analgesik.
Kelompok perlakuan tiga ekstrak daun kucai dosis 14,4 mg, hasil menunjukkan adanya respon nyeri dilihat dari setelah pemberian bahan uji pada menit ke 30 terjadi penurunan respon tikus hingga menit ke 120 . Hal ini menunjukkan bahwa ekstrak daun kucai dosis 14,4 mg memiliki efek analgesik. Ini dapat disebabkan oleh faktor patologik yang menyebabkan efek obat dalam hal ini ekstrak daun kucai menurun (Setiawan, 2010).

Pada penelitian ini kelompok perlakuan tiga ekstrak daun kucai dosis 14,4 mg memiliki efek analgetik yang paling baik dibandingkan dengan kelompok perlakuan ekstrak dosis 3,6 mg dan 7,2 mg karena dari sebelum pemberian bahan uji hingga menit ke 120 jumlah rata-rata respon tikus mengalami penurunan secara bertahap dapat dilihat pada tabel 1. Bila dibandingkan dengan kelompok kontrol positif yang diberi paracetamol, efek analgetik dari ekstrak daun kucai lebih rendah dari parasetamol.

Grafik dan diagram rata-rata penurunan respon tikus menunjukkan bahwa dosis $14,4 \mathrm{mg}$ merupakan dosis yang memiliki efek analgesik paling tinggi dari ketiga dosis ekstrak yang digunakan. Jika dibandingkan dengan kontrol positif, pemberian ekstrak lebih rendah. Pada kelompok kontrol negatif yang diberikan CMC $1 \%$ tidak memiliki kemampuan dalam menurunkan rasa nyeri karena tidak mengandung zat aktif yang terbukti dari rata-rata penurunan respon tikus paling tinggi dibandingkan dengan kelompok perlakuan lainnya.

Dari ketiga kelompok perlakuan ekstrak etanol daun kucai dengan dosis yang berbeda-beda, hasil penelitian ini membuktikan bahwa secara farmakologi ekstrak etanol daun kucai memiliki efek analgesik. Ekstrak daun kucai memiliki efek analgesik karena adanya kandungan senyawa flavonoid (Al-Snafi, 2013). Menurut Christina et al., (2012), senyawa flavonoid berperan sebagai analgesik dengan cara menghambat kerja enzim siklooksigenase dengan mengurangi produksi prostaglandin oleh asam arakidonat sehingga dapat mengurangi rasa nyeri.

\section{KESIMPULAN}

Berdasarkan hasil penelitian, dapat disimpulkan bahwa ekstrak etanol daun kucai (Allium tuberosum) memiliki efek analgesik pada tikus putih jantan (Rattus norvegicus) pada dosis 3,6 mg, 7,2 $\mathrm{mg}$, dan 14,4 mg. 


\section{SARAN}

Dari hasil peneltian ini disarankan kepada penelitian selanjutnya agar dapat dilakukan penelitian lebih lanjut mengenai penentuan dosis minimum, maksimum dan dosis toksik agar ditemukan dosis yang optimal.

\section{DAFTAR PUSTAKA}

Al-Snafi, A. E. 2013. Review Articel: Pharmacological Effects Of Allium Species Grown In Iraq. Int. J. Pharm. \& H. Care Res. 1(4): 142-144.

Andarwulan, N., Faradilla, R. H. F. 2012. Senyawa Fenolik Pada beberapa Sayuran Indigenius dari Indonesia. Bogor: Southeast Asian Food and Agricultural Science nd Technology (SEAFAST) Center, IPB. 9:57-60.

Anief, M. 2000. Prinsip Umum dan Dasar Farmakologi. UGM Press. Yogyakarta.

Christiana, I., Evacuasiany, E., Hidayat, M. 2012. The Analgetic Effect Of Kayu Rapat Bark Infusion (Parameria leavigata (Juss) Moldenke) On Male Mice Treated With Termal Induction. Jurnal Medika Planta. 2(1): 107-109
Guyton, A.C. and J.E. Hall 2007. Buku Ajar Fisiologi Kedokteran. EGC, Jakarta.

Guyton, A.C. and J.E. Hall 2011. Buku Ajar Fisiologi Kedokteran. Elsevier, Singapore.

Mantiri, N.C., Awaloei, H., Posangi, J. 2013. Perbandingan Efek Analgesik Perasan Rimpang Jahe Merah (Zingiber officinale var. Rubrum Thelaide) Dengan Aspirin Dosis Terapi Pada Mencit (Mus musculus) [skripsi]. Bagian Farmakologi dan Terapi, Universitas Sam Ratulangi Manado.

Setiawan, R. 2010. Pengaruh Pemberian Ekstrak Kelopak Bunga Roela (Hibiscus sabdariffa L.) Terhadap Penurunan kadar Gula Darah Tikus Putih (Rattus novergicus) yang Diinduksi Aloksan [skripsi]. Fakultas Kedokteran Universitas Sebelas Maret, Surakarta.

Tjay, T. H., Rahardja, K. 2002. Obat-obat Penting Khasiat Penggunaan dan Efek-efek Sampingnya. PT Alex Komputindo. Jakarta.

Wijayakusuma, H. 2001. Penyembuhan dengan Bawang Putih dan Bawang Merah. Penerbit Milenia Popular, Jakarta. 